\title{
Assessing the Economic Burden and Determinants of Violence among Households in Ogun State, Nigeria
}

\author{
Babalola D A ${ }^{1}$, Omeonu $\mathrm{P} \mathrm{E}^{2}$, Agbede $\mathrm{C} \mathrm{O}^{2}$, Odewusi $\mathrm{T} \mathrm{A}^{3}$ and \\ Olanrewaju $\mathrm{M} \mathrm{F}^{2}$ \\ ${ }^{I}$ Department of Agricultural Economics and Extension, School of Agric \& Ind. Tech, Babcock University, \\ Ilishan-Remo, Ogun State, Nigeria \\ ${ }^{2}$ Department of Public Health, Babcock University, Ilishan-Remo, Ogun State, Nigeria. \\ ${ }^{3}$ Department of Nursing Science, Babcock University, Ilishan-Remo, Ogun State, Nigeria.
}

\begin{abstract}
The paper examined the incidence, economic burden and determinants of domestic violence among households in Odogbolu community of Ogun state. Primary data were collected from 80 respondents purposively selected. Data collected were analyzed using the descriptive statistics. Results showed that mean age of the respondents was 35, mean years of educational was 8 years and average household size was 6 . Some $67 \%$ of the respondents earned above $\$ 20,000$ per month, $45 \%$ have experienced one form of domestic violence or the other. Further results showed that domestic violence exists among households in the study area. In-law's influence, extra marital affairs, polygamy, poor education and alcohol/substance use were the major determinants domestic violence. Economic burden of domestic violence among respondents included cost of treatment of injured victims and loss of work output. The majority (53\%) of the households with incidence of violence were farming households. Interventions of spiritual/traditional leaders (67\%), counselors/social workers (63\%) are foremost in respondents' coping strategies for domestic violence. The study recommends community-based efforts encouraging women economic empowerment to reduce poverty and food insecurity and fostering unity of the nuclear family and discouraging unhealthy interference of extended family members in the affairs of the household.
\end{abstract}

Keywords: economic burden, income, Ogun, violence

\section{Introduction}

Violence and the household- two terms that should be mutually exclusive but tragically, however, they are not. The incidence of domestic violence is on the rise in general societies and it usually begins in the household [1,2]. Societies in Nigeria are not immune. Domestic violence has both emotional and economic implication on the society. Many behavioral ills in the society have been traced to originate from violent homes.

In economic theory, the household is regarded as the primary economic unit because apart from being the primary consumption unit for the output of the firms, the household supplies the needed labour for production [3]. Emotional stability, which can be jeopardized by domestic violence, is essential for labour productivity even though it cannot be measured in quantitative terms. The nexus between social welfare and the wealth of a nation has also been established $[4,5]$. Welfare is a state of the mind which reflects human happiness and satisfaction. As violence can diminished the happy state of human mind, it can cause a decline in social welfare. Pigou [4] argued that even economic welfare, which is a component of social welfare, does not depend solely on the amount of income earned but also on the living condition and psychological wellbeing of individual households in the nation. One reason posited is that as a result of increase in their expenditure proportionately to income, the total welfare cannot be presumed to have increased, if they spend their increased income on harmful commodities like alcohol, cigarette, gambling etc which are synonymous with household suffering from violence. Children directly or indirectly influenced by domestic violence often suffer diminished academic welfare [6].

A study such as this, which analyses domestic violence among households, especially emphasizing amelioration, is of immediate importance and relevance, especially as the nation is faced with increasing economic hardship and insurgence of terrorism.

\subsection{Kinds of Actions Considered as Domestic Violence}

Domestic violence statutes in most country apply not only to physical attacks, but also to other types of conduct. Generally, domestic violence, according to ABA [7]; Reid [6], can be classified into physical abuse and emotional abuse. Physical abuse involves hitting, punching, slapping, kicking, shoving, choking, biting, pinching, and assault with any object that can cause injury (which could include the use of knife, broken bottle 
or even gun). Emotional abuse involves Verbal abuse, Constant criticism, disturbance at a spouse's place of work, making harassing telephone calls, stalking, degrading remarks, name calling, accusations and threats (even though the threat may not have been carried out). Verbal abuse does not leave telltale scars and bruises, but the damage can be even greater. Constant criticism, degrading remarks, name calling, accusations and threats injure people's feelings, erode their self-esteem and can fill them with fear and uncertainty, as well as hatred. Threats to hit or kill the other person, to leave, or take the children away, or withdraw financial support may cause the other partner to live in fear. Emotional abuse such as this is psychologically traumatic.

\subsection{Domestic violence- who is the target?}

According to Taylor [8], men physically and emotionally abuse their wives and children because of several reasons. The first reason is that they can. Generally, men are taught that it is all right to be rough and mean. Society has allowed men to be abusive to their wives and families. When we hear of a man abusing his wife, often a question is asked of the woman "what did you do to make him get so mad?" Or "You need to be more understanding of your husband." Even when a woman is being physically or emotionally abused by her husband/partner, she is made to believe that she is in the wrong and not her husband. Women are to be quiet, soft, sweet, gentle and passive. Men are indirectly and directly encouraged by their mothers and fathers to always be in charge and in control of situations.

\subsection{The Aftermath of Domestic Violence}

Family violence can play havoc with a child's mental, emotional and physical development. Watching and listening to abusive parents leaves emotional scars, including:

- Low self-esteem

- Mixed feelings toward parents

- Lack of trust

- Anxiety in anticipating the next outbreak of violence

- Guilt and depression in feeling responsible for the abuse

- Fear of abandonment

The abused children are told that they are bad, uncontrollable, unloved [9]. Abused wives are persuaded by their husbands that they are incompetent, hysterical, and frigid [10]. This brainwashing that accompanies with family abuse is potent because families are the primary group in which most individuals construct reality. Children who are abused may fail to thrive physically or may have speech and hearing problems. They often suffer from stress-related illness such as headaches and stomach aches. Children in violent homes may be aggressive or extremely passive. They often experience problems in school. There is a higher rate of juvenile delinquency and substance abuse among the youngsters. Teenagers often escape violent homes into early marriages or pregnancies.

Reid [6] posited that violence is a learned behavior. Children who grow up in violent homes learn that violence is an acceptable way to handle conflict. They learn by example that it is all right to hurt someone you love. What children do not learn is equally devastating. They do not learn about healthy relationships, about managing their feelings, or about solving problems in a positive way.

This is a common entrapment to all types of family abuse. The abuse often goes on for an extended period of time so much that the victims have difficulty stopping it, avoiding it, or leaving entirely [11]. Victims of different types of domestic violence report surprisingly similar long term pattern: depression, suicidal feelings, self contempt and an inability to trust or develop intimate relationships in later life $[10,11]$

The United States statistics have shown that the cost of treating injury sustained by victims as aftermath of domestic violence can be as high or even exceeds $\$ 5.8$ billion each year, $\$ 4.1$ billion of which is for direct medical and mental health services [12]. The report further reveal that victims of domestic violence, especially women, lost almost 8 million days of paid work because of the violence perpetrated against them by current or former husbands, boyfriends and dates. This loss is the equivalent of more than 32,000 full-time jobs and almost 5.6 million days of household productivity as a result of violence.

\subsection{Factors Leading to Domestic Violence}

Small arms can be diverted from licit to illicit uses - a weapon legally purchased for hunting purposes can be used to kill, threaten or intimidate an intimate partner. Despite the emphasis among law enforcement on illegal small arms and crime, legal firearms are the primary weapons used in domestic homicides in many countries. A gun in the home is much more likely to be used to intimidate or physically injure family members than be used against an outside intruder. A 2003 study from the USA shows that having a gun in the home increased the overall risk of someone in the household being murdered by $41 \%$, but for women in particular the risk was nearly tripled [13]. 
According to Steven [14], the concept of male headship of the household is supported and defended by many cultures and religions in Africa. Abusive men often cite male headship or female submissiveness to justify their abuse. Ultimately, this is based on a perverted assumption of male superiority. The importance of defining male headship in terms of loving equality between the man and the woman cannot be overemphasized. Physical and sexual abuse by men is shockingly prevalent in many Nigerian cultures. Domestic violence perpetrated by males account for more adult female emergency room visits than traffic accidents, muggings, and rapes combined. While trying to mediate, most traditional and spiritual leaders often advocate women submissiveness and acceptance of violence [15].

Most men and women who abuse their partners either watched abuse in their family as they were growing up or were abused themselves as children. They have low self-esteem and usually are controlling and jealous. They often easily lose their temper and become verbally or physically violent. They also may have strong traditional views of male and female roles.

Abuse may also arise from abuse of power. Straus et al [16] showed that families where a woman has less power by virtue of not being in the labor market or excluded from participating in decision making, she is at higher risk of abuse. It has also been noted that men often start to beat their wives when these women try to assert themselves in some ways or establish some degree of independence [11]. Men often resort to sexually abuse their children when they are unemployed or failing financially or suffered some setbacks [17].

Violence behaviour may be induced by violent-prone personality. Straus et al [16] identified a number of past characteristics especially in children that could predict future violence. This included witnessing, receiving, or committing violent acts in the childhood home; violent acts toward pets, inanimate objects, or other people; having a criminal record; being in military service; previous violent behavior towards women. Added to these are the following: history of temper tantrums, insecurity, jealousy and possessiveness.

1.5 Common Social and Institutional Response

A number of philanthropic concerned groups and non-governmental organization including religious institutions are making efforts to curb the menace of domestic violence. Services such as counseling, rehabilitation, financial empowerment and other welfare aids are being offered by these organizations [18]. However, most communities still believe that certain forms of violence between couples such as slapping or pushing are normative and should not be labeled spouse abuse [16, 19].

Physicians and the medical institution play instrumental role in intervention into the child abuse problem. As a result of the little physical injury involved in most cases of sexual abuse especially spouse abuse, physicians have shown low level of response. The reason for this differential response requires further studies. Similarly, the role of the police and prosecutors can be examined for the contrasting manner of their response to the different forms of abuse. The police appear to be most heavily involved in the problem of spouse abuse, and to a lesser extent in the problem of physical child abuse.

In order to add to and corroborate existing literature on the subject of domestic violence, a survey of selected households in Odogbolu community of Ogun state to analyze the incidence and determinants of domestic violence in order to ameliorate its social and economic burden in the study area.

\section{Methodology}

The study area, Odogbolu, is a prominent agrarian community in Ogun state, Nigeria. Major economic activity is farming and most of the agribusiness activities are carried out by women. Its proximity to Lagos and Oyo states (the two most populous states in south-west Nigeria) made farming a profitable venture in the community. Well structured questionnaire was used to gather data from respondents from Odogbolu community. One hundred respondents, who were adults, were purposively selected; however, eighty respondents gave responses useful for the purpose of analysis. The data collected were subjected to analysis using the descriptive statistics.

\section{Result And Discussion}

Result according to Table 1 showed that mean age of the respondents is 35 years which implies that they are part of the active work force and whatever affects them negatively will significantly affect their contribution to economic growth. Their educational level, though relatively low (mean $=8$ years), shows that they can read and write and interpret information passed on in the English language. It is also expected that they should be able to relate positively to intervention programmes and technologies transfer [20]. Respondents had moderate household size (mean $=6$ ) judging from the state average of 5 [21]. The mean number of years in marriage for the respondents was 11 years and majority (67\%) earned above $\$ 20,000$ per month. Majority of the respondents are female $(64 \%)$ and are married $(68 \%)$. Thirty-six out of eighty respondents $(45 \%)$ have experienced one form of domestic violence or the other.

Respondents reported their awareness of the existence of all forms of violence (Table 2). However, among the physical violence considered, physical abuse of children (beating) is highest (63\%). Among the 
emotional violence, abuse caused by straying spouse (90\%), constant criticism (90\%) and quarreling using bad language (90\%) were observed highest. Result showed that the respondent perceived that the main reasons why the victims of domestic violence decides to cover or choose not to report the experience are to cover shame $(100 \%)$, to protect the spouse or family name $(100 \%)$ and anticipation of reconciliation $(100 \%)$.

Table 1: Basic Descriptive Statistics of Respondents Specific Characteristics

\begin{tabular}{|c|c|c|c|c|c|c|}
\hline Variables & Mean & Min & $\operatorname{Max}$ & No. of Respondents & $(n=80)$ & $\%$ \\
\hline Age (years) & 35 & 18 & 62 & & & \\
\hline Education (years) & 8 & 0 & 16 & & & \\
\hline Spouse Education (years) & 14 & 0 & 21 & & & \\
\hline Family Size & 6 & 2 & 9 & & & \\
\hline \multicolumn{7}{|l|}{ Household monthly income ( } \\
\hline$<20,000$ & & & & 27 & & 34 \\
\hline $20,000-50,000$ & & & & 38 & & 48 \\
\hline$>50,000$ & & & & 15 & & 19 \\
\hline \multicolumn{7}{|l|}{ Gender } \\
\hline Male & & & & 29 & & 36 \\
\hline Female & & & & 51 & & 64 \\
\hline \multicolumn{7}{|l|}{ Marital Status } \\
\hline Married & & & & 54 & & 68 \\
\hline Single & & & & 26 & & 32 \\
\hline Years of Marriage & 11 & 0 & 23 & & & \\
\hline \multicolumn{7}{|l|}{ Experience with violence } \\
\hline Yes & & & & 36 & & 45 \\
\hline No & & & & 44 & & 55 \\
\hline
\end{tabular}

Source: Field Survey, 2013

Table 2: Respondents Perception of Violence Variables among households

\begin{tabular}{lc}
\hline Variables & Frequency (n=80) \\
\hline Kinds of violence & \% \\
Wife/husband beating & 36 \\
Physical abuse/beating of children & 51 \\
Sexual assault of partner & 36 \\
Sexual abuse of children by parent & 24 \\
Sexual abuse of children by other relatives/siblings & 42 \\
Emotional abuse caused by straying spouse & 72 \\
Constant criticism/degrading remarks & 75 \\
Name calling/quarreling using bad language & 30 \\
Accusation and threats & 53 \\
Reasons why the abused cover violence experience & 90 \\
To cover shame & 90 \\
To protect their spouse/family name & 90 \\
Intimidation by the violent partner & 66 \\
Fear of losing financial support from the erring partners & 83 \\
Fear of divorce & 80 \\
Consideration for the effect on children/extended family & 80 \\
Acceptance of husband as lord i.e. he has all right & 100 \\
Anticipation of reconciliation & 72 \\
\hline Source: Field Survey, 2013 & 90 \\
\end{tabular}

Source: Field Survey, 2013

These results are considered with past studies. The submission of Butler [22] revealed that abused victims of domestic violence are often overtaken by feelings of intense shame and thus keep the experience a secret. Walker [10] also posited that the victims often believed that the abuse will stop by certain effort from them.

Results in Table 3 shows that 53 percent of the households with the incidence of domestic violence are farming households. This has a lot of implication on agricultural production in the study area. Results also show that the usual victims of domestic violence are mostly women (44\%). The majority of the respondents (50\%) reported that violence associated with injury seldom occur however, 33 percent reported experiencing frequent cases of injured victims as a result of domestic violence. Also, households (42\%) seldom seek medical treatment for injury associated with violence. This might be because the injury is mild or for the shame or legal implication of reporting the cause of the injury. Whatever may be the reasons for not seeking treatment from the appropriate healthcare giver, domestic violence predisposes injured victims to self medication and further infections. Although $42 \%$ claimed that they did not incur cost for treating violence injury, some $58 \%$ expended money for treatment, in fact, about $22 \%$ spent as much as $\$ 10,000$ in treating injury associated with each case of domestic violence. Since many of the households are low income earners (Table 1), this certainly will constitute great burden on the economic wellbeing of the affected households if not checked. Further results 
show that occurrence of violence impact work output (50\% for moderately to high impact). This may directly or indirectly impact agrarian activities in the study area since most of the respondents are farmers.

Table 3: Distribution of Burden of Domestic Violence among Household with Incidence

\begin{tabular}{|c|c|c|}
\hline Variables & Frequency $(n=36)$ & $\%$ \\
\hline \multicolumn{3}{|l|}{ Occupation } \\
\hline Trading & 8 & 22 \\
\hline Artisans & 4 & 11 \\
\hline Civil service/Clerical & 5 & 14 \\
\hline Farming & 19 & 53 \\
\hline \multicolumn{3}{|l|}{ Usual victim } \\
\hline Husband & 9 & 25 \\
\hline Wife & 16 & 44 \\
\hline Children & 11 & 31 \\
\hline \multicolumn{3}{|l|}{ Frequency of occurrence } \\
\hline Once & 12 & 33 \\
\hline More than once but Infrequent & 14 & 38 \\
\hline Frequent & 10 & 28 \\
\hline \multicolumn{3}{|l|}{ Frequency of injury occurrence } \\
\hline None & 6 & 17 \\
\hline Infrequent & 18 & 50 \\
\hline Frequent & 12 & 33 \\
\hline \multicolumn{3}{|c|}{ Frequency of seeking medical treatment for injury } \\
\hline None & 14 & 38 \\
\hline Infrequent & 17 & 42 \\
\hline Frequent & 5 & 14 \\
\hline \multicolumn{3}{|c|}{ Approx. treatment cost per case of injury (\#) } \\
\hline None & 15 & 42 \\
\hline$<5,000$ & 10 & 28 \\
\hline $5,000-10,000$ & 8 & 22 \\
\hline$>10,000$ & 3 & 8 \\
\hline \multicolumn{3}{|c|}{ Impact of occurrence on work day loss } \\
\hline None & 18 & 50 \\
\hline Moderate & 15 & 42 \\
\hline High & 3 & 8 \\
\hline
\end{tabular}

Source: Field Survey, 2013

Table 4 shows that all factors considered were strong determinants of domestic violence as perceived by respondents; however, influence of in-laws is strongest (100\%). Result in Table 5 further revealed that majority of respondents $(67 \%)$ preferred to resolve domestic violence by seeking the intervention of spiritual or traditional rulers. Very few of the respondents had ever sought court injunction, police intervention or resorted to divorce. Past studies have shown that many Nigerians have little faith in the integrity or capacity of the police or legal system to redress crimes of domestic abuse or are not ready to face the humiliating rules regarding evidence in court $[8,23]$. In checking domestic violence, majority of the respondents $(90 \%)$ recommended that offenders should be disciplined, followed by the involvement of counselors $(63 \%)$.

Table 4: Determinants of Domestic Violence

\begin{tabular}{llc}
\hline Factors that can lead to violence & Frequency & \% \\
\hline Illiteracy in both/one of the partners & 48 & 60 \\
Poverty & 72 & 90 \\
Low income level & 72 & 90 \\
In-law's influence & 80 & 100 \\
Polygamy & 78 & 98 \\
Extra marital affair & 78 & 98 \\
Psychological pressure & 66 & 83 \\
Pressure at work/nature of work & 66 & 83 \\
Peer pressure & 72 & 90 \\
Traditional view of gender role (man is supreme) & 72 & 90 \\
Laws protecting victims are not well enforced & 72 & 90 \\
Family background (spouse from violent homes) & 78 \\
Abuse of alcohol/drug use & 78 & 98 \\
Spouse living in separate homes & 78 \\
Partners with complex & 78 \\
Jealous partners & 78 \\
Too large family & 68 & 98 \\
\hline
\end{tabular}

Source: Field Survey, 2013 
Table 5: Respondents Experience with Domestic Violence and Coping Strategies

\begin{tabular}{lcc}
\hline Variables & Frequency & \% \\
\hline Coping Strategies (n=36) & 8 & 22 \\
Court injunction & 10 \\
Divorce & 18 \\
Relations and friends rallied round & 24 \\
Seeking intervention of traditional/spiritual leaders & 4 & 28 \\
Seeking intervention of police & 12 \\
Got counseling & 40 \\
Learnt to live with it & 47 \\
Ways of checking violence (n=80) & 11 \\
Phone the police & 33 \\
Involve counselors & 51 \\
Offender/guilty person should be disciplined & 72 \\
Seminars on violence should the conducted & 36 \\
\hline
\end{tabular}

Source: Field Survey, 2013

IV. Conclusions And Recommendation

The paper examined the incidence, economic burden and determinants of domestic violence among households in Odogbolu community of Ogun state. Primary data were collected from 80 respondents. Results showed that domestic violence exists among households in the study area. In-law's influence, extra marital affairs, polygamy, low level of education and alcohol or substance use were among the dominant factors leading to domestic violence. Economic burden of domestic violence among respondents included cost of treatment of injured victims and loss of work output. Agriculture is mostly hit since majority of the households are farmers. News of incidence is not popularly heard because victims (mostly women) are too ashamed to report or believe covering the story will facilitate reconciliation. Interventions of spiritual or traditional leaders, counselors or social workers are foremost in the recommendations of the respondents for ameliorating domestic violence.

Based on the findings of this study the following have been recommended:

1. Government community-based effort should incorporate women economic empowerment projects to reduce poverty and food insecurity that are both a cause and effect of domestic violence.

2. Public enlightenment programmes and community-based educational seminars should be enhanced especially focusing on fostering unity of the nuclear family and discouraging unhealthy interference of extended family members in the affairs of the household. This can be achieved by collaborative efforts of the media, social workers, local government agencies in charge of family planning and religious institutions.

3. Finally, school curricular should incorporate health education that highlights the ills of alcohol and substance use, which is a major factor enhancing the incidence of physical violence.

\section{References}

[1]. Wilcox, W.B, Soft Patriarchs, New Men: How Christianity Shapes Fathers and Husbands. University of Chicago Press, 2004 , 181 82.

[2]. Ellison, Christopher G, Ethnicity, Religious Involvement, and Domestic Violence, Violence Against Women 13(11), 2007, 93-110

[3]. Olayemi J. K, Principle of microeconomics for applied economic analysis, SICO Publisher, Ibadan, 2004 ISBN 978-006-432-X

[4]. Pigou A.C,The economies of welfare. New York, 1932. pp. 11

[5]. Jhingan, M. L, Macroeconomic Theory. Vrinda Publications, Delhi, 2004. p. 37-44

[6]. Reid J. M, Preventing Violence in the Home. Available at www.surfinthespirit.com, 2010, retrieved June 17, 2010

[7]. ABA, American Bar Association: What kinds of Actions is Considered Domestic Violence? Family Legal Guide, 2004, available at www.ABAfamilylegalguide.com, retrieved June 18, 2010.

[8]. Taylor Leonie, Domestic Violence: The Problem Pervading Nigeria. Available at www.thinkafricapress.com, 2012, retrieved September, 2013

[9]. Herbruck, Breaking the Cycle of Child Abuse. Minneapolis: Winston press, 1979.pp.4

[10]. Walker, L, The Battered Woman. New York: harper \& Row, 1979.p.15

[11]. Gelles, R, Abusive Wives: why do they stay? Journal of Marriage and Family, 1976, 38:659-669

[12]. NCIPC, National Centers for Injury Prevention and Control report: Costs of Intimate Partner Violence against Women in the United States. 2003. Bulletin of the Centers for Disease Control and Prevention, NCIPC. Atlanta, GA, 2003.

[13]. Wiebe, D. J, Homicide and Suicide Risks Associated with Firearms in the Home: A National Case Control Study, Annals of Emergency Medicine, 41, 2003. American College of Emergency Physicians.

[14]. Steven, Tracy, Headship with a Heart: How Biblical Patriarchy Actually Prevents Abuse, Christianity Today, 2003.

[15]. Obi, S. N. and B.C. Ozumba, Factors associated with domestic violence in South-East Nigeria. Journal of obstetrics and gynaecology, 27(1), 2007, $75-78$.

[16]. Straus, M; Gelles, R and Steinmetz, S, Behind Closed Doors: Violence in American Family. New York: Doubleday, 1980.

[17]. Meiselman, K, Incest. San Francisco: Jossy-Bass, 1978, pp. 23

[18]. Matins, D, Battered Wives. New York: Pocket books, 1976, pp.10

[19]. Finkerhor, D, Sexually Victimized Children. New York: free Press, 1982 
Assessing the Economic Burden and Determinants of Violence among Households in Ogun State,

[20]. Babalola D A; Y T Babalola and A A Oladimeji, Assessing the Use of Family Planning Information among Farming Households in Nigeria: Evidence from Ogun State. Asian Journal of Rural Development 2(2), 2012, 40-46.

[21]. NBS, Nigeria Bureau of Statistics. Annual abstract of statistics, produced under the auspices of Federal Government Economics Reform and Governance Project (ERGP), 2009. Available online at www.nigerianstat.gov.ng

[22]. Butler, S, Conspiracy of Silence. San Francisco: New Glide, 1978.

[23]. NCADV, National Coalition Against Domestic Violence: fact sheet, 2012, Available at www.ncadv.org, retrieved September, 2013 